\title{
313 溶射皮膜の機械的性質とスプラット形態の関係
}

Relationship between mechanical property and splat morphology of spray coatings

沖 幸男 (近畿大学 理工学部)

Sachio OKI, Kin-Ki University, Kowakae 3-4-1, Higashi-Osaka, Osaka

Key words : spray pattern, splat morphology, adhesive strength,

\section{1. 緒 言}

著者はすでに，溶射皮膜の表面形態を定量解析し，その特性 值の分布から溶射皮膜の形成機構を推定することが可能であ ることを示した. ${ }^{1,2)}$ また, スプラット形態と密着力などの関 係が明らかになれば, 表面形態から皮膜特性を推測することが 可能になる.

一方, 通常の溶射では, 溶射ガンあるいはワークを駆動させ て広い面積に皮膜を形成する.このとき，溶射粒子はガンの中 心軸からある広がりを持って飛行し, スプレーパターンを形成 する. 溶射ガンあるいはワークを駆動させながら溶射する場合， 常にこのスプレーパターン周辺部を飛行してきた粒子が皮膜 最表面に堆積すると考えられる. そこで, 皮膜内部を構成する スプラット形態と表面形態との関係を明らかにするためスプ レーパターンの解析を行い, スプレーパターン中心部と周辺部 のスプラット形態の違いを検討した. その結果, スプレーパタ ーン中心部は, よく押し広げられた不規則の形状のスプラット で構成されており，周辺部に行くにしたがって小さな円形のス プラットが支配的になっていった ${ }^{3)}$. すなわち, スプレーパタ ーン周辺部は, 温度・速度ともに低い溶着粒子によって構成さ れることになる.

以上の結果から, 通常の溶射ではスプレーパターン周辺部を 通過した溶射粒子がまず基材に到着し，その後，スプレ一パタ ーン中心部を通過した粒子が積層し, 最後に，また周辺部を通 過した粒子が堆積することが明らかになつた。このように， 溶射皮膜はさまざまな特性を持ったスプラットの積層構造で 構成される. さらに, 皮膜の密着性を支配すると考えられる基 材と溶射皮膜の界面を構成する溶射粒子は, スプレーパターン 周辺部を飛行してきたものである. 一般にこれらの粒子はその スプラト形態からも推測されるように, 温度, 速度ともに低く, 粒子の接合力は低いと考えられる.したがって，スプレーパタ 一ン周辺部の飛行粒子を除去することが出来れば, 密着力の向
上が期待できる.

このような観点から，黒鉿製スリットを用いてスプレーパタ 一ン周辺部を飛行する粒子を除去することを試みた. このよう にして得られた溶射皮膜の密着力と皮膜の耐磨耗性ならびに 皮膜を構成するスプラットの形態を検討した.

\section{2. 実験方法}

本研究で用いた原料粉末は, 平均粒径 $21.5 \mu \mathrm{m}$ の球状アルミ ナ粉末（昭和電工， CB-A20S）である. 溶射には, BayState 社 製 P-120 プラズマ溶射ガン（40 kW 級）を装着した大気溶射装 置を使用し，溶射距離， $d s$ を $100 \mathrm{~mm}$ 一定にして試料の調製を 行った．溶射カンと基材の間に黒鈶製のスリットを配置し，ス プレーパターン周辺部の溶射粒子を除去した. 比較のため, ス リットを用いない通常の溶射による試験片も作製した.

密着強さの試験にはФ $5 \mathrm{~mm}$ のピンテスト試験片を用いた. 溶 射後の試験片は, インストロン型試験機でピンを引き抜き, 密 着強さを求めた. 耐磨耗性はスガ式磨耗試験で評価した. スプ ラットの形態は，等価円の直径， D eq，と形状係数，Fs，で評 価した．得られたスプレーパターン表面を走查型電子顕微鏡 （SEM）で観察し，画像解析により Deq とFS を測定し，特性值 の分布によってそれぞれの位置におけるスプラットの形態を 評価した.

\section{3. 実臨結果}

スプレーガンと基材との間に黒鈶製スリットを装着するこ とによって，スプレーパターン周辺部を飛行する粒子を除去 することが出来た.この方法によって周辺部を飛行する粒子を 除去した皮膜の密着強さはFig. 1 に示したように, 通常の溶 射によるものに比べ明らかに向上した. また, 通常の溶射では, ピンテスト後のピン表面には皮膜がほとんど残っておらず, 基 材と皮膜の界面で破断したことは明らかである. 一方, 周辺部 
を飛行する粒子を除去した皮膜の場合, ピンテスト後のピン表 面の大部分が溶射皮膜で覆われており皮膜内部で破断したも のと考えられる.この結果からも，スプレーパターン周辺部を 飛行する粒子を除去することによる密着強さ向上の理由が推 測できる.

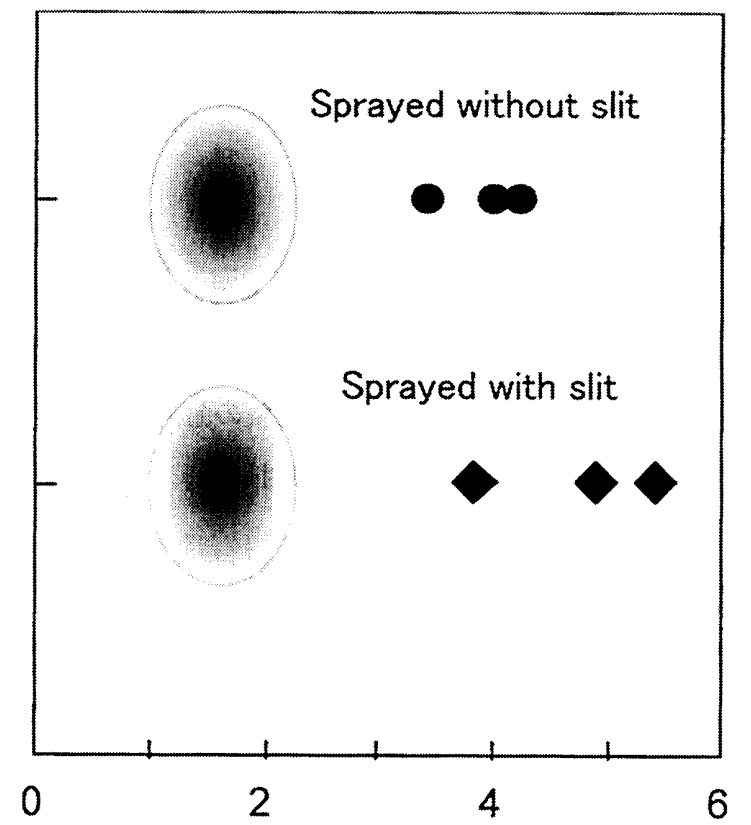

Adhesive strength / MPa

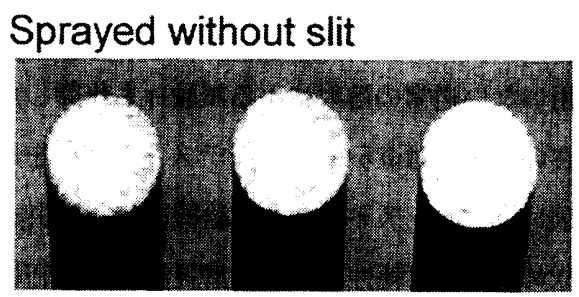

\section{Sprayed with slit}

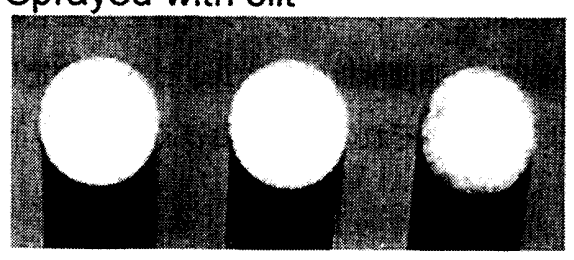

Fig. 1 Adhesive strength and fractured surface of coatings.

次に，磨耗試験の結果を Fig. 2 に示した。この場合も密着 力と同様, スリットを用いて周辺部を飛行する粒子を除去した 方が幾分高い耐磨耗性を示した。

次に，皮膜表面のスプラットの形態を Fig. 3 に示した．ス プレーパターン周辺部を飛行する粒子を除去した皮膜では, Deq とFs がともに小さい領域のスプラットがほとんど含まれ
ていない.このような形態のスプラットは, スプレーパターン 周辺部に見られるものであり，スリットの効果が明確に現れて いる. また，皮膜の表面に見られるスプラット形態と基材と皮 膜界面のスプラット形態は同様のものであり，界面から，Deq と $F_{\mathrm{S}}$ がともに小さい領域のスプラットを除去することによっ て密着強さが向上することを示している.

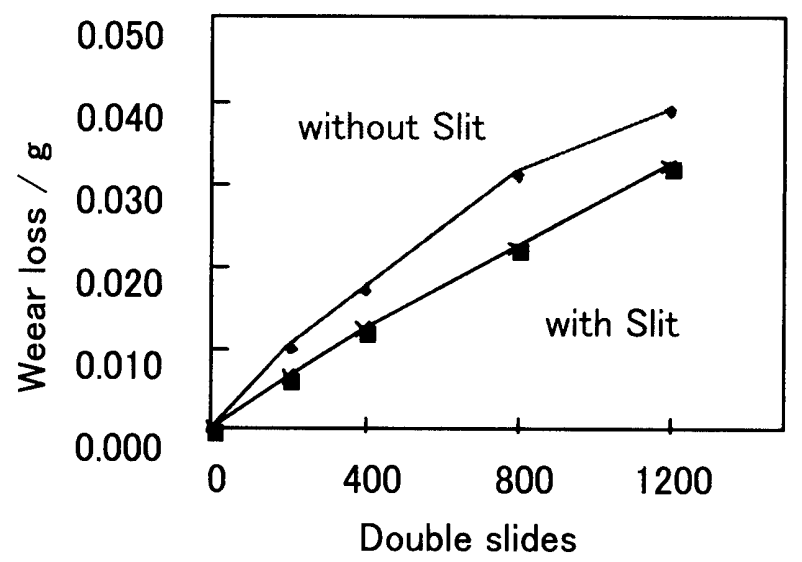

Fig. 2 Wear property of spray coatings.

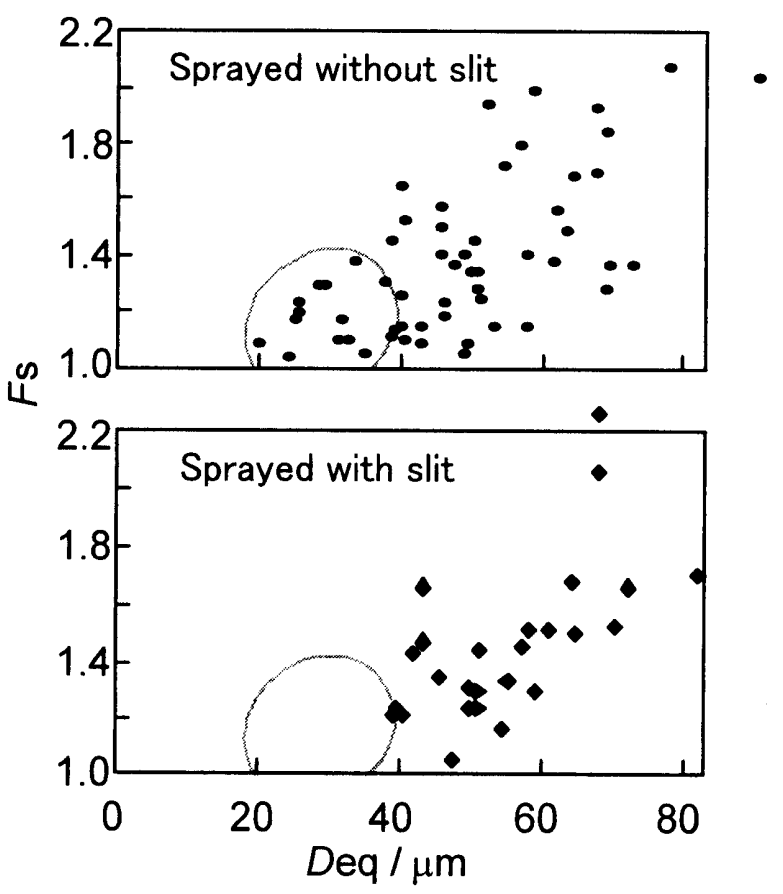

Fig. 3 Splat morphology of spray coating.

1）沖幸男, 山川昌文, 合田 進; 溶射, 35 (1998), pp. 274-282.

2）沖幸男；溶射，36（1999），pp. 182-188.

3）沖 幸男; 溶射， 38 (2001)，pp. 23-27. 